Cite this: Dalton Trans., 2014, 43 6614

Received 21st February 2014, Accepted 25th February 2014

DOI: $10.1039 / c 4 d t 00545 \mathrm{~g}$

www.rsc.org/dalton

\section{Pentadienyl chemistry of the heavy alkaline-earth metals revisited $\uparrow$}

\author{
Matthias Reiners, Ann Christin Fecker, Matthias Freytag, Peter G. Jones and \\ Marc D. Walter*
}

Open-metallocenes of the heavy alkaline-earth metals $\left[\left(\eta^{5}-\mathrm{Pdl}^{\prime}\right)_{2}-\right.$ $M(\text { thf })_{n}$ ] (M = Ca (1), Sr (2), $n=1 ; M=B a(3), n=2 ; \mathrm{Pdl}^{\prime}=2,4-$ $t \mathrm{Bu}_{2} \mathrm{C}_{5} \mathrm{H}_{5}$ ) are readily prepared by salt-metathesis between $\mathrm{MI}_{2}$ and KPdl' and characterized by NMR spectroscopy and X-ray diffraction studies.

Over the last decade organometallic calcium, strontium and barium complexes have attracted some interest, ${ }^{1-3}$ e.g. as precursors for metalorganic vapour deposition (MOCVD) ${ }^{4,5}$ or as catalyst systems in polymerisation and hydrofunctionalization reactions. ${ }^{6-9}$ Nevertheless, the isolation and characterization of these highly reactive compounds required the development of suitable ligands and synthetic techniques. In this context, the $\eta^{5}$-coordinate cyclopentadienyl ligand has played a prominent role in stabilizing half-sandwich and metallocene complexes. ${ }^{10-16}$ More recently, these investigations have been extended to allyl systems, which can adopt both $\pi-\left(\eta^{3}\right)$ and $\sigma$ - $(\kappa C)$ bonding modes. ${ }^{17-25}$ Pentadienyls, with their ability to adopt $\kappa C$-, $\eta^{3}$ - and $\eta^{5}$-coordination modes, occupy an intermediate position between the cyclopentadienyl and allyl systems, and their coordination chemistry with transition metals has been well established. ${ }^{26-31}$ Surprisingly, reports on group 2 complexes $\left(\mathrm{Be},{ }^{32} \mathrm{Mg},{ }^{33}\right.$ and $\mathrm{Ca}^{34}$ ) show only two of them are structurally characterized, $\left[\left(\kappa C-2,4-\mathrm{Me}_{2} \mathrm{C}_{5} \mathrm{H}_{5}\right)_{2} \mathrm{Mg}\right.$ (tmeda) $]^{33}$ and $\left[\left(\eta^{5}-\mathrm{Pdl}^{\prime}\right)_{2} \mathrm{Ca}(\mathrm{thf})\right]\left(\mathrm{Pdl}^{\prime}=2,4-t \mathrm{Bu}_{2} \mathrm{C}_{5} \mathrm{H}_{5} ; \mathbf{1}\right) .{ }^{34}$ Overby and Hanusa report that the $\mathrm{Pdl}^{\prime}$ ligand provides only limited solubility, thus precluding the synthesis of the open metallocenes of the heavier homologues, $\mathrm{Sr}$ and $\mathrm{Ba},{ }^{34}$ but this is in contrast to the general observation that sterically demanding substituents such as $t \mathrm{Bu}$ and $\mathrm{SiMe}_{3}$ enhance solubility and stabilize the corresponding metal complexes. For instance, several heavy alkaline-earth metal complexes have

Institut für Anorganische und Analytische Chemie, Technische Universität, Braunschweig, Hagenring 30, 38106 Braunschweig, Germany.

E-mail: mwalter@tu-bs.de; Fax: +49 531391 5387; Tel: +49 5313915312

$\dagger$ Electronic supplementary information (ESI) available: Experimental, NMR, crystallographic and computational data. CCDC 982693-982696. For ESI and crystallographic data in CIF or other electronic format see DOI: $10.1039 / \mathrm{c} 4 \mathrm{dt} 00545 \mathrm{~g}$ been successfully prepared with $t$ Bu-substituted cyclopentadienyl, ${ }^{5,35,36}$ pyrrolyl $^{37}$ and P-heterocyclic ${ }^{38,39}$ ligands, and all exhibit good solubility in aliphatic and aromatic hydrocarbon solvents. Within our research program on pentadienyl ligands, ${ }^{40}$ we therefore decided to revisit the heavy alkalineearth metals.

The potassium salt $\mathrm{KPdl}^{41}$ was prepared according to a modified literature procedure $\dagger$ and can be crystallized as its thf-adduct from saturated THF solutions at $-30^{\circ} \mathrm{C}$. + A snapshot of the molecular structure of $\left[(\text { thf }) K\left(\mu-\eta^{5}: \eta^{5}-\mathrm{Pdl}^{\prime}\right)\right]_{\infty}$ is shown in Fig. 1 and reveals that the U-shaped $\eta^{5}-\mathrm{Pdl}^{\prime}$ anion is coordinated in the solid state by two potassium cations to form a zigzag polymeric chain via a $2_{1}$ screw axis. Selected bond distances and angles are listed in Table 1 . The $\mathrm{C}-\mathrm{C}$ bond distances within the pentadienyl moiety (C1-C5) follow the typical short-long-long-short pattern. The conformation angle $\chi$ is defined as the angle between the two planes, [centroid (C1-C5)-C3-M] and [centroid(C1'-C5')-C3'-M], and allows the mutual orientation of the two pentadienyl moieties to be quantified. In $[(\text { thf }) \mathrm{K}(\mu-\mathrm{Pdl})]_{\infty}$ the pentadienyl ligands adopt a nearly anti-ecliptic conformation with $\chi=178.5^{\circ}$, thereby minimizing repulsive interactions between the sterically demanding $t \mathrm{Bu}$-groups.

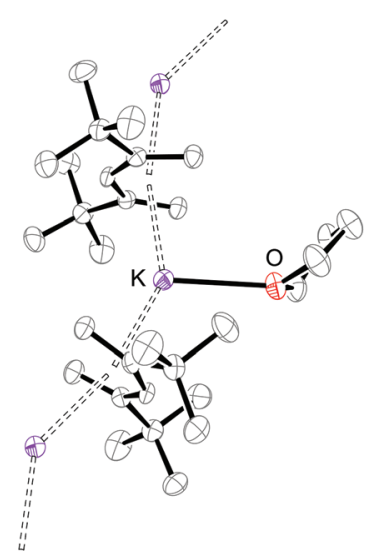

Fig. 1 ORTEP diagram of $\left[(\text { thf }) K\left(\mu-P d l^{\prime}\right)\right]_{x}(50 \%$ probability ellipsoids). 


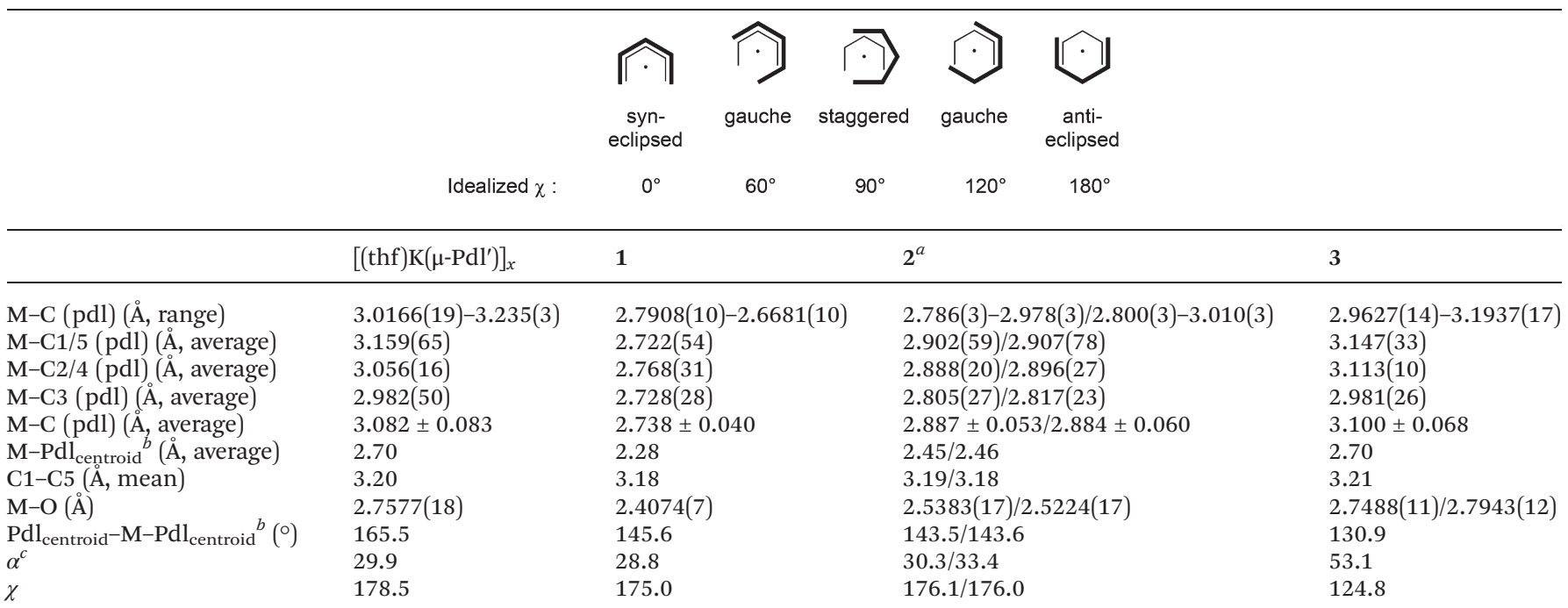

${ }^{a}$ Two independent molecules in the asymmetric unit. ${ }^{b} \mathrm{Pdl}_{\text {centroid }}$ is the centroid of the pentadienyl ligand. ${ }^{c} \alpha$ is defined as the angle formed by the two dienyl planes.

In contrast to the previous report, ${ }^{34}$ the salt metatheses of two equivalents of $\mathrm{KPdl}^{\prime}$ with $\mathrm{MI}_{2}(\mathrm{M}=\mathrm{Ca}, \mathrm{Sr}, \mathrm{Ba})$ proceed smoothly at ambient temperature and yield the corresponding open-metallocenes $\left[\left(\eta^{5}-\mathrm{Pdl}\right)_{2} \mathrm{M}(\mathrm{thf})_{n}\right](\mathrm{M}=\mathrm{Ca}(\mathbf{1}), \mathrm{Sr}(\mathbf{2}), n=1$; $\mathrm{M}=\mathrm{Ba}(3), n=2)$ in crystalline form and moderate yields (eqn (1)).†

$$
\begin{gathered}
2 \mathrm{KPdl}^{\prime}+\mathrm{MI}_{2} \underset{\mathrm{M}=\mathrm{Ca}, \mathrm{Sr}, \mathrm{Ba}}{\longrightarrow}\left[\left(\eta^{5}-\mathrm{Pdl}^{\prime}\right)_{2} \mathrm{M}(\mathrm{thf})_{n}\right]+2 \mathrm{Kl} \\
\mathrm{M}=\mathrm{Ca}(1) ; n=1 \\
\mathrm{M}=\mathrm{Sr}(2) ; n=1 \\
\mathrm{M}=\mathrm{Ba}(3) ; n=1
\end{gathered}
$$

Nevertheless, we also found that the anionic Pdl' ligand behaves as a strong base and readily undergoes radical coupling to 2,4,7,9-tetra-tert-butyl-1,3,7,9-decatetraene. ${ }^{41,42}$ Therefore, it is imperative for the synthesis of these complexes to use metal iodides $\mathrm{MI}_{2}$ of high purity. Trace amounts of $\mathrm{NH}_{3}$ or $\mathrm{I}_{2}$ as a result of the $\mathrm{MI}_{2}$ preparation must be removed, otherwise the yield of the salt metathesis reaction is dramatically reduced and insoluble material is obtained. However, pure open-metallocenes 1-3 are readily soluble in aliphatic hydrocarbons (pentane, hexane), aromatic solvents (benzene, toluene) and ethers (tetrahydrofuran, diethyl ether), and can readily be crystallized as their thf adducts from concentrated pentane solutions at $-30{ }^{\circ} \mathrm{C} . \$$ Since our synthetic protocol yields very soluble products, we also recorded ${ }^{1} \mathrm{H}$ and ${ }^{13} \mathrm{C}\left\{{ }^{1} \mathrm{H}\right\}$ NMR spectra in $\mathrm{C}_{6} \mathrm{D}_{6}$ of these complexes and as expected, the NMR spectra of these complexes are very similar. In addition, no dynamic behaviour of the Pdl' ligands is observed at ambient temperature in solution. $\dagger$

The molecular structures of 2 and 3 are shown in Fig. 2, and relevant bond distances and angles are listed in Table 1 . In addition significantly improved X-ray diffraction data for the open-calcocene $\mathbf{1}$ were obtained, so we decided, for a
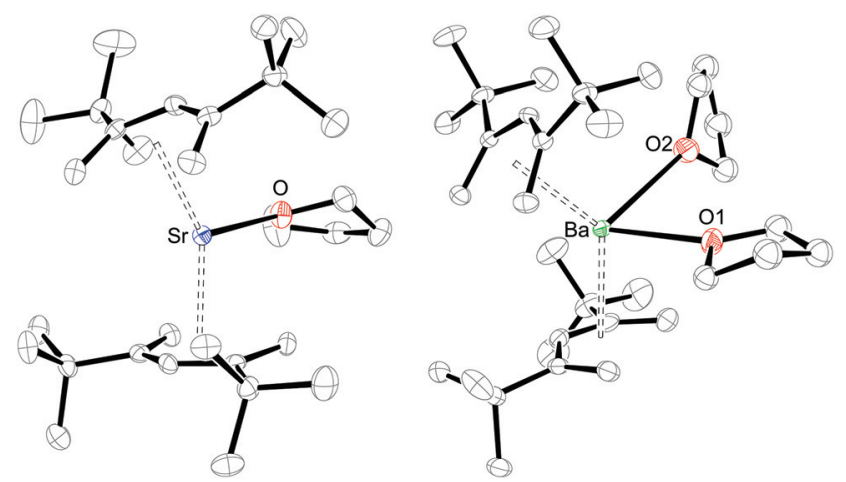

Fig. 2 ORTEP diagrams of 2 and 3 (50\% probability ellipsoids). For 2 only one of the two independent molecules in the asymmetric unit is shown. For 3 the two thf molecules are disordered over two positions, but only one conformation is shown.

better comparison, to include our data in Table 1. In all cases, the Pdl' ligand adopts a $\eta^{5}-\mathrm{U}$ coordination mode and the structural features of these complexes resemble those of $\mathbf{1}$, except that two THF ligands are coordinated in the case of $\mathrm{Ba}$. Whereas one THF ligand resides in the usual position at the open edge of one Pdl' ligand, the second THF molecule is positioned at the backside of the second pentadienyl ligand. In $\left[\left(\eta^{5}-2,4-\mathrm{Me}_{2} \mathrm{C}_{5} \mathrm{H}_{5}\right)_{2} \mathrm{Zr}(\mathrm{CO})_{2}\right]$ the two $\mathrm{CO}$ ligands feature a similar orientation with respect to the dienyl ligands. ${ }^{43}$ The conformational angles $\chi$ range from $175^{\circ}$ for $\mathbf{1}$ to $124.8^{\circ}$ for 3 and the predominant driving force for these arrangements is the minimization of repulsive interactions between the $\mathrm{Pdl}^{\prime}$ and thf ligands. Furthermore, the $\mathrm{C}-\mathrm{C}$ distances within the pentadienyl system show a distinct short-long-long-shortpattern. Previous studies on $\left[\left(\eta^{5}-2,4-\mathrm{Me}_{2} \mathrm{C}_{5} \mathrm{H}_{5}\right)_{3} \mathrm{Nd}\right]$, which also shows ionic bonding between the dienyl ligand and the metal cation, established that the $\mathrm{M}-\mathrm{C}$ bonds to the formally 
charged C1-, C3-, and C5-positions are shorter than those to the uncharged C2- and C4-positions. ${ }^{44}$ For the complexes 1-3 the $\mathrm{M}-\mathrm{C}$ distances vary significantly and the shortest is found to be the central carbon atom of the Pdl' ligand (C3-position) consistent with the observation on $\left[\left(\eta^{5}-2,4-\mathrm{Me}_{2} \mathrm{C}_{5} \mathrm{H}_{5}\right)_{3} \mathrm{Nd}\right]$. However, the average Ca-C1/5 distances $(2.722(54) \AA)$ in $\mathbf{1}$ are essentially identical to the average $\mathrm{Ca}-\mathrm{C} 3$ distances (2.728(28) $\AA$ ), a different trend is observed for the heavier homologues 2 and 3, for which the average $\mathrm{M}-\mathrm{C} 2 / 4$ and $\mathrm{M}-\mathrm{C} 1 / 5$ bonds become progressively longer (Table 1 ). The increase in the average $\mathrm{M}-\mathrm{C}$ distances of $2.738(40) \AA$ in 1 to $3.100(68) \AA$ in 3 nicely mirrors the increase in ionic radii for heptacoordinate $\mathrm{Ca}^{2+}(1.06 \AA)$ and $\mathrm{Sr}^{2+}(1.21 \AA)$ and octacoordinate $\mathrm{Ba}^{2+}$ $(1.40 \AA) .{ }^{45}$ These observations can be compared to those in metal-allyl complexes, for which average $\mathrm{M}-\mathrm{C}$ distances in $\left[\left(\eta^{3}-1,3-\left(\mathrm{Me}_{3} \mathrm{Si}_{2} \mathrm{C}_{3} \mathrm{H}_{3}\right)_{2} \mathrm{Ca}(\mathrm{thf})_{2}\right] \quad(2.654(4) \AA),{ }^{17}\left[\left(\eta^{3}-\mathrm{C}_{3} \mathrm{H}_{5}\right)_{2}(\right.\right.$ trigylme- $\left.\left.\kappa^{4}\right)\right](2.727(72) \AA),{ }^{46}$ and $\left[\left(\eta^{3}-1,3-\left(\mathrm{Me}_{3} \mathrm{Si}_{2}\right)_{2} \mathrm{C}_{3} \mathrm{H}_{3}\right)_{2} \mathrm{Sr}(\mathrm{thf})_{2}\right]$ $(2.801 \AA)^{21}$ are found. All attempts to prepare a momomeric allyl $\mathrm{Ba}$ analogue resulted in the formation of a heterometallic barium/potassium complex, $\left[\mathrm{K}(\mathrm{thf}) \mathrm{Ba}_{2}\left(1,3-\left(\mathrm{Me}_{3} \mathrm{Si}_{2} \mathrm{C}_{3} \mathrm{H}_{3}\right)_{5}\right]{ }^{21}\right.$ This further supports the important features of the pentadienyl fragment in the stabilization of the heavy-alkaline earth metals by adopting an intermediate position between the allyl and cyclopentadienyl fragments. Furthermore, the average $\mathrm{M}-\mathrm{C}(\mathrm{M}=\mathrm{Ca}, \mathrm{Sr}, \mathrm{Ba})$ bond distances in 1-3 are longer than those in the related metallocenes, e.g. $\left[\left(\eta^{5}-1,3-\left(\mathrm{Me}_{3} \mathrm{Si}_{2}\right)_{2} \mathrm{C}_{5} \mathrm{H}_{3}\right)_{2^{-}}\right.$ $\mathrm{M}($ thf $)]\left(\mathrm{M}=\mathrm{Ca}(2.678(14) \AA),{ }^{47} \mathrm{Sr}(2.82 \AA)^{48}\right)$ and $\left[\left(\eta^{5}-1,2,4-\right.\right.$ $\left.\left.\left(\mathrm{Me}_{3} \mathrm{C}\right)_{3} \mathrm{C}_{5} \mathrm{H}_{2}\right)_{2} \mathrm{Sr}(\mathrm{thf})\right](2.87 \AA) .{ }^{35}$ This presumably indicates a more flexible and therefore weaker metal-ligand bonding in the pentadienyl systems, and therefore a hapticity switch should be relatively facile in the open group 2 metallocenes.

\section{Conclusions}

We have extended the series of group 2 open-metallocenes to $\mathrm{Sr}$ and $\mathrm{Ba}$ and established a reliable synthetic protocol that allows the preparation of synthetically useful quantities. In all cases the Pdl' ligand adopts a $\eta^{5}-\mathrm{U}$ coordination mode in the solid state and in solution. It can be expected that the other group 2 open-metallocenes are also accessible and that they exhibit broad reactivity towards unsaturated molecules. These and related studies are ongoing and will be reported in due course.

\section{Acknowledgements}

MDW acknowledges the financial support from the TU Braunschweig through the "Zukunftsfonds" and from the Deutsche Forschungsgemeinschaft (DFG) through the Emmy Noether program (WA 2513/2).

\section{Notes and references}

\$Crystal data for $\left[(\text { thf }) \mathrm{K}\left(\mu-\eta^{5}: \eta^{5}-\mathrm{Pdl}^{\prime}\right)\right]_{\infty}: \mathrm{C}_{17} \mathrm{H}_{31} \mathrm{KO}, M=290.52$, orthorhombic, $a=10.1190(2) \AA, b=10.7148(6) \AA, c=16.4367(9) \AA, V=1782.11(14) \AA^{3}, T=130(2)$
$\mathrm{K}$, space group $P 2_{1} 2_{1} 2_{1}, Z=4$ (monomers), $\mu(\mathrm{CuK} \alpha)=2.5 \mathrm{~mm}^{-1}, 18651$ reflections measured, 3697 independent reflections $\left(R_{\mathrm{int}}=0.108\right)$. The final $R_{1}$ values were $0.0498(I>2 \sigma(I))$ and 0.0572 (all data). The final $w R\left(F^{2}\right)$ values were 0.1245 $(I>2 \sigma(I))$ and 0.1304 (all data). The goodness of fit on $F^{2}$ was 1.02.

Crystal data for 1: $\mathrm{C}_{30} \mathrm{H}_{54} \mathrm{OCa}, M=470.81$, monoclinic, $a=9.9014(2) \AA, b=$ 21.7075(4) $\AA, c=14.4003(3) \AA, \beta=105.501(2)^{\circ}, V=2982.56(10) \AA^{3}, T=100(2) \mathrm{K}$, space group $P 2_{1} / n, Z=4, \mu(\mathrm{MoK} \alpha)=1.9 \mathrm{~mm}^{-1}, 78853$ reflections measured, 6171 independent reflections $\left(R_{\text {int }}=0.048\right)$. The final $R_{1}$ values were $0.0296(I>$ $2 \sigma(I))$ and 0.0306 (all data). The final $\mathrm{w} R\left(F^{2}\right)$ values were $0.0785(I>2 \sigma(I))$ and 0.0794 (all data). The goodness of fit on $F^{2}$ was 1.05 .

Crystal data for 2: $\mathrm{C}_{30} \mathrm{H}_{54} \mathrm{OSr}, M=518.35$, triclinic, $a=9.7948(5) \AA ⿻$ 14.1834(5) $\AA, c=23.3962(10) \AA, \alpha=88.549(3)^{\circ}, \beta=79.821(2)^{\circ}, \gamma=71.131(2)^{\circ}, V=$ $3025.4(2) \AA^{3}, T=100(2) \mathrm{K}$, space group $P(\overline{1}), Z=4, \mu(\mathrm{MoK \alpha})=1.8 \mathrm{~mm}^{-1}, 132306$ reflections measured, 15422 independent reflections $\left(R_{\mathrm{int}}=0.111\right)$. The final $R_{1}$ values were $0.0544(I>2 \sigma(I))$ and 0.1022 (all data). The final $\mathrm{w} R\left(F^{2}\right)$ values were $0.0724(I>2 \sigma(I))$ and 0.0825 (all data). The goodness of fit on $F^{2}$ was 1.04 .

Crystal data for 3: $\mathrm{C}_{34} \mathrm{H}_{62} \mathrm{BaO}_{2}, M=640.18$, triclinic, $a=9.5411(3) \AA, \quad b=$ 12.0829(3) $\AA, c=15.6171(5) \AA, \alpha=96.320(2)^{\circ}, \beta=97.530(3)^{\circ}, \gamma=98.661(3)^{\circ}, V=$ 1748.97(9) $\AA^{3}, T=100(2) \mathrm{K}$, space group $P(\overline{1}), Z=2, \mu(\mathrm{MoK \alpha})=1.2 \mathrm{~mm}^{-1}, 92321$ reflections measured, 10431 independent reflections $\left(R_{\mathrm{int}}=0.031\right)$. The final $R_{1}$ values were $0.0222(I>2 \sigma(I))$ and 0.0262 (all data). The final $\mathrm{w} R\left(F^{2}\right)$ values were $0.0493(I>2 \sigma(I))$ and 0.0514 (all data). The goodness of fit on $F^{2}$ was 1.05 .

1 M. Westerhausen, Z. Anorg. Allg. Chem., 2009, 635, 13.

2 S. Krieck, L. Yu, M. Reiher and M. Westerhausen, Eur. J. Inorg. Chem., 2010, 197.

3 M. Westerhausen, J. Langer, S. Krieck, R. Fischer, H. Goerls and M. Koehler, Top. Organomet. Chem., 2013, 45, 29.

4 W. A. Wojtczak, P. F. Fleig and M. J. Hampden-Smith, Adv. Organomet. Chem., 1996, 40, 215.

5 T. Hatanpää, M. Vehkamaeki, I. Mutikainen, J. Kansikas, M. Ritala and M. Leskelae, Dalton Trans., 2004, 1181.

6 M. Labet and W. Thielemans, Chem. Soc. Rev., 2009, 38, 3484 .

7 C. A. Wheaton, P. G. Hayes and B. J. Ireland, Dalton Trans., 2009, 4832.

8 S. Harder, Chem. Rev., 2010, 110, 3852.

9 A. G. M. Barrett, M. R. Crimmin, M. S. Hill and P. A. Procopiou, Proc. R. Soc. London, Ser. A, 2010, 466, 927.

10 T. P. Hanusa, Chem. Rev., 1993, 93, 1023.

11 D. J. Burkey and T. P. Hanusa, Comments Inorg. Chem., 1995, 17, 41.

12 H. Sitzmann, T. Dezember and M. Ruck, Angew. Chem., Int. Ed., 1998, 37, 3114.

13 P. Jutzi and N. Burford, Chem. Rev., 1999, 99, 969.

14 M. J. Harvey, K. T. Quisenberry, T. P. Hanusa and V. G. Young Jr., Eur. J. Inorg. Chem., 2003, 3383.

15 M. D. Walter, G. Wolmershäuser and H. Sitzmann, J. Am. Chem. Soc., 2005, 127, 17494.

16 L. Orzechowski, D. F. J. Piesik, C. Ruspic and S. Harder, Dalton Trans., 2008, 4742.

17 M. J. Harvey, T. P. Hanusa and V. G. Young Jr., Angew. Chem., Int. Ed., 1999, 38, 217.

18 K. T. Quisenberry, C. K. Gren, R. E. White, T. P. Hanusa and W. W. Brennessel, Organometallics, 2007, 26, 4354.

19 S. C. Chmely, C. N. Carlson, T. P. Hanusa and A. L. Rheingold, J. Am. Chem. Soc., 2009, 131, 6344.

20 S. C. Chmely, T. P. Hanusa and W. W. Brennessel, Angew. Chem., Int. Ed., 2010, 49, 5870. 
21 K. T. Quisenberry, R. E. White, T. P. Hanusa and W. W. Brennessel, New J. Chem., 2010, 34, 1579.

22 P. Jochmann, T. S. Dols, T. P. Spaniol, L. Perrin, L. Maron and J. Okuda, Angew. Chem., Int. Ed., 2010, 49, 7795.

23 C. Lichtenberg, P. Jochmann, T. P. Spaniol and J. Okuda, Angew. Chem., Int. Ed., 2011, 50, 5753.

24 P. Jochmann, S. Maslek, T. P. Spaniol and J. Okuda, Organometallics, 2011, 30, 1991.

25 P. Jochmann, J. P. Davin, S. Maslek, T. P. Spaniol, Y. Sarazin, J.-F. Carpentier and J. Okuda, Dalton Trans., 2012, 41, 9176.

26 R. D. Ernst, Struct. Bonding, 1984, 57, 1.

27 R. D. Ernst, Acc. Chem. Res., 1985, 18, 56.

28 P. Powell, Adv. Organomet. Chem., 1986, 26, 125.

29 R. D. Ernst, Chem. Rev., 1988, 88, 1255.

30 R. D. Ernst, Comments Inorg. Chem., 1999, 21, 285.

31 L. Stahl and R. D. Ernst, Adv. Organomet. Chem., 2007, 55, 137.

32 H. Yasuda, Y. Ohnuma, A. Nakamura, Y. Kai, N. Yasuoka and N. Kasai, Bull. Chem. Soc. Jpn., 1980, 53, 1101.

33 H. Yasuda, M. Yamauchi, A. Nakamura, T. Sei, Y. Kai, N. Yasuoka and N. Kasai, Bull. Chem. Soc. Jpn., 1980, 53, 1089.

34 J. S. Overby and T. P. Hanusa, Angew. Chem., Int. Ed. Engl., 1994, 33, 2191.

35 F. Weber, H. Sitzmann, M. Schultz, C. D. Sofield and R. A. Andersen, Organometallics, 2002, 21, 3139.
36 T. Hatanpää, M. Ritala and M. Leskela, J. Organomet. Chem., 2007, 692, 5256.

37 H. Schumann, J. Gottfriedsen and J. Demtschuk, Chem. Commun., 1999, 2091.

38 M. Westerhausen, M. H. Digeser, H. Noeth, W. Ponikwar, T. Seifert and K. Polborn, Inorg. Chem., 1999, 38, 3207.

39 M. D. Francis, P. B. Hitchcock and J. F. Nixon, Chem. Commun., 2000, 2027.

40 A. C. Fecker, A. Glöckner, C. G. Daniliuc, M. Freytag, P. G. Jones and M. D. Walter, Organometallics, 2013, 32, 874.

41 R. D. Ernst, J. W. Freeman, P. N. Swepston and D. R. Wilson, J. Organomet. Chem., 1991, 402, 17.

42 J. S. Overby and T. P. Hanusa, Acta Crystallogr., Sect. C: Cryst. Struct. Commun., 1994, 51, 313.

43 T. E. Waldman, L. Stahl, D. R. Wilson, A. M. Arif, J. P. Hutchinson and R. D. Ernst, Organometallics, 1993, 12, 1543.

44 R. D. Ernst and T. H. Cymbaluk, Organometallics, 1982, 1, 708.

45 R. Shannon, Acta Crystallogr., Sect. A: Cryst. Phys., Diffr., Theor. Gen. Cryst., 1976, 32, 751.

46 P. Jochmann, T. S. Dols, T. P. Spaniol, L. Perrin, L. Maron and J. Okuda, Angew. Chem., Int. Ed., 2009, 48, 5715.

47 P. Jutzi, W. Leffers, G. Müller and B. Huber, Chem. Ber., 1989, 122, 879.

48 L. M. Engelhardt, P. C. Junk, C. L. Raston and A. H. White, J. Chem. Soc., Chem. Commun., 1988, 1500. 